\title{
A COMPARISON OF THERMAL AND DYE DILUTION METHODS OF DETERMINING CARDIAC OUTPUT
}

\author{
J. Colin Kay, a.I.M.L.T.(ENG.) and \\ WilliaM H. Noble, M.D., DiP.ANAES. (TOR.), F.R.C.P. (c)
}

\section{INTRODUCTION}

CARDIAC OUTPUT is being estimated in clinical settings using variations of the Fick principle and indicator dilution methods.

If perfect steady state conditions could be achieved, the Fick method would give an accurate determination of cardiac output. In acutely ill patients the use of a mouth piece or face mask for expired gas collection might influence the patient's breathing pattern, thus producing a change in oxygen uptake. Combined with the need for right heart catheterization, this may prevent a steady state from being achieved. Difficulties also arise in the analysis of samples when the Fick method is applied during anaesthesia with gaseous or volatile agents. ${ }^{1}$

The indicator dilution method usually consists of a rapid injection of an accurately measured quantity of indicator into the venous circulation and analysis of the blood indicator concentration as a function of time at some point in the arterial system. Recirculation of the indicator is one of the main disadvantages of this method, as it makes calculation of the area under the primary circulation curve difficult.

The most popular indicator is indocyanine green dye, which has several disadvantages. Accurate calibration of dye-dilution curves is difficult and timeconsuming. The slope of dye calibration in an individual patient is unique for that patient. ${ }^{2}$ Frequent recalibration is necessary because, in critically ill patients, progression of disease and treatment may produce changes in haematocrit and in the optical characteristics of blood. ${ }^{3}$

In order to overcome these problems investigators have searched for new indicators. Fegler ${ }^{4}$ used cool blood or Ringer's Solution, and by recording the temperature-time curves of blood in the aorta and pulmonary artery found thermodilution curves similar to dye-dilution curves. The indicator in this case is heat. This thermodilution technique offers the advantages of: (a) virtually unlimited repeatability, as any physiological solution can be used as an indicator; (b) ease of calibration; (c) minimal recirculation due to dissipation of heat in the peripheral tissues; (d) relatively uncomplicated instrumentation; and (e) blood withdrawal is not essential.

The experiments reported here were done to evaluate the accuracy and reliability of the thermodilution method in comparison with the dye-dilution technique in normal dogs and in dogs with gross pulmonary oedema.

Dept. of Anaesthesia, St. Michael's Hospital and University of Toronto. 


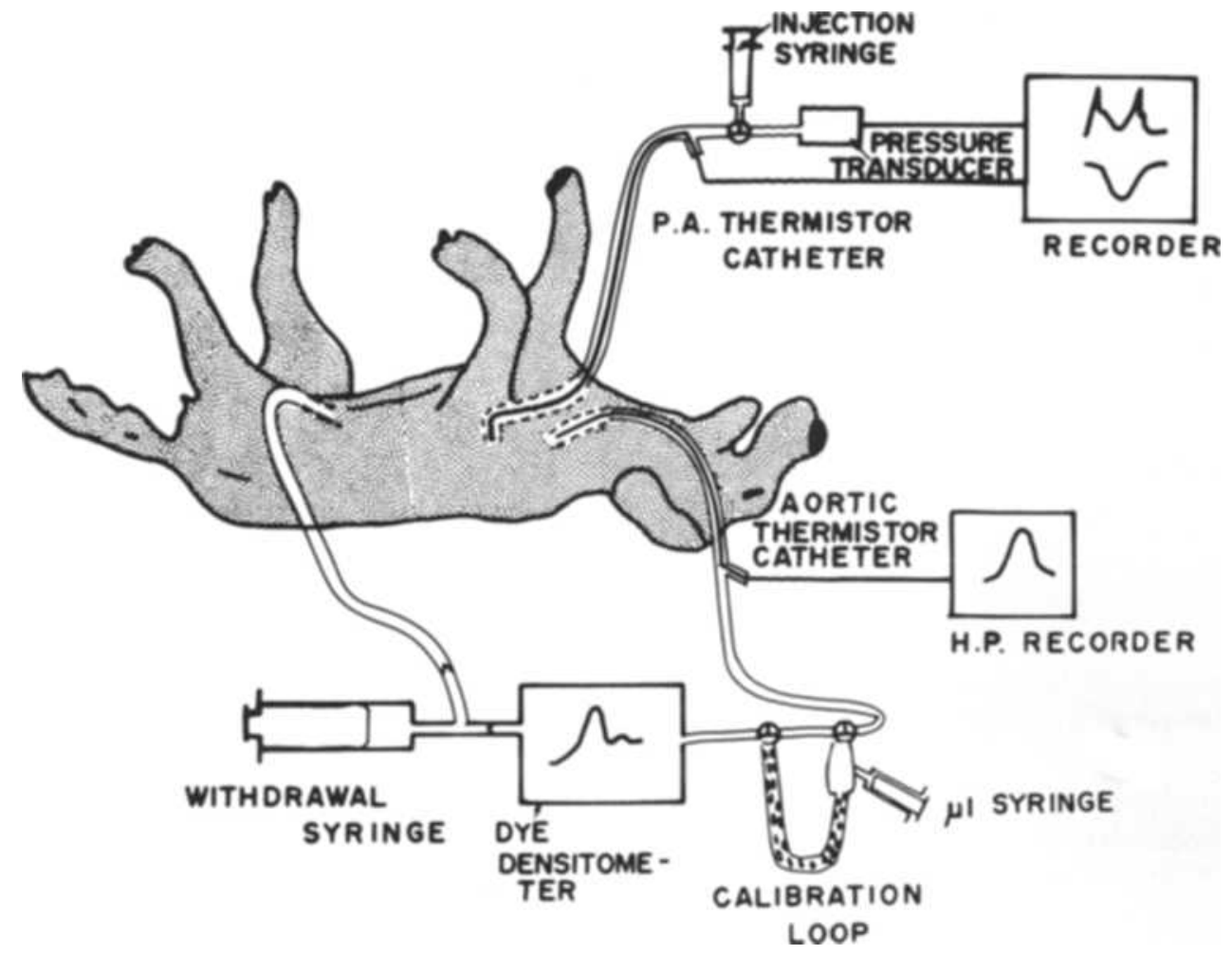

Figure 1. Diagram of measuring system.

\section{METHODS}

Six mongrel dogs ranging in weight from 20 to $27 \mathrm{Kg}$ were anaesthetized with pentobarbitone (Nembutal) ( 20 to $30 \mathrm{mg} / \mathrm{Kg}$ intravenously). A tracheostomy was performed and the dogs were allowed to breath spontaneously while lying supine. Arterial and venous femoral catheters were inserted to monitor pressure and to infuse drugs.

A flexible injection catheter was connected to a pressure transducer, passed down the external jugular vein and floated into the pulmonary artery, using pressure measurements to locate its tip. Initially, placement in the pulmonary artery frequently required 1 to 2 hours. Now, using a flow directed catheter constructed entirely of silastic the procedure takes five minutes. The catheter is approximately $60 \mathrm{~cm}$ long, has an inner diameter of $0.062 \mathrm{in}$., an outer diameter of $0.095 \mathrm{in}$., with two or three small side holes at a maximum distance of $2 \mathrm{~cm}$ from the end. To measure the temperature of the injectate at the point of entry into the circulation a Yellow Springs Instrumentation subcutaneous thermistor probe \#511 was placed inside this catheter, just proximal to the side holes (Figure 1).

A sensing catheter was then passed down the internal carotid artery so that the tip was just distal to the aortic valve. The sensing catheter also contained a thermistor probe near its tip. Placement of the thermistor within the catheter prevented contact with the aortic wall.

The recording of thermodilution curves requires accurate measurement of small 
temperature changes. The injection of indicator at room temperature into the pulmonary artery is followed by temperature changes in the aorta of approximately 0.1 to $0.2^{\circ} \mathrm{C}$. Thermistors are excellent temperature sensing devices for this purpose because of their great sensitivity to small temperature changes. They are available in very small sizes which can be easily inserted into conventionally used catheters. They have an almost logarithmic temperature resistance characteristic, which may be electronically altered to be made virtually linear. The current through the thermistor is kept small enough to minimize heating, otherwise the thermistor would become sensitive to variations in flow. ${ }^{5}$

The thermistors we used had an onset delay of 0.044 second and an exponential time constant of 0.188 second resulting in a time delay constant of 0.232 second. The thermistors were excited by direct current and incorporated into one arm of a Wheatstone bridge. The bridge was balanced and the change in output amplified and recorded on a direct writing recorder. The recorder gave a $1 \mathrm{~cm}$ deflection per $4^{\circ} \mathrm{C}$ change for the injectate catheter and a $1 \mathrm{~cm}$ deflection per $0.02^{\circ} \mathrm{C}$ change for the sensing catheter.

The sensing thermistor was calibrated by placing it in a constantly stirred water bath and recording the deflection for each $0.1^{\circ} \mathrm{C}$ temperature change through a range from $35^{\circ} \mathrm{C}$ to $41^{\circ} \mathrm{C}$. The water bath temperature was measured with a mercury thermometer. The injectate catheter thermistor was calibrated in a similar manner but over a range from $20^{\circ} \mathrm{C}$ to $40^{\circ} \mathrm{C}$.

For each determination of thermodilution cardiac output (Q⿱中一)), the injecting catheter was flushed with 3 per cent saline and then left to equilibrate to body temperature; $5 \mathrm{ml}$ of 3 per cent saline at room temperature was then injected rapidly, by hand, into the pulmonary artery, while recording the temperature and pressure from the injectate catheter. From these recordings the change of temperature between dog blood and injectate was measured. The time of injection was determined from the pressure trace, the mean being $0.97 \pm 0.09$ second. The injectate volume delivered by the syringe was determined by weighing. A Harvard pump withdrew blood through the sensing catheter at $43 \mathrm{ml} / \mathrm{min}$ so that a temperature-time curve was recorded on a Hewlett Packard recorder. After each determination blood was reinfused through the femoral vein. The cardiac output was obtained from the following equation: ${ }^{5}$

Where:

$$
\dot{Q}_{T}=\frac{\left(V_{T}-V_{I}\right) d_{1} S_{1} \Delta T_{1}}{d_{b} s_{b} \int_{0}^{\infty} \Delta T_{b} t_{b} d t}
$$

$\mathrm{V}_{\mathbf{T}}=$ total volume delivered from injection syringe:

$V_{\mathrm{I}}=$ volume of injectate in the portion of catheter inside the dog and therefore at dog temperature;

$\mathrm{d}_{1}=$ density of injectate;

$S_{1}=$ specific heat of injectate;

$\Delta \mathrm{T}_{1}=$ change of temperature between $\operatorname{dog}$ blood and injectate;

$\mathrm{d}_{\mathrm{b}}=$ density of blood;

$\mathrm{s}_{\mathrm{b}}=$ specific heat of blood;

$\int_{0}^{\infty} \mathrm{T}_{\mathrm{b}} \mathrm{t}_{\mathrm{b}} \mathrm{dt}=$ area under the temperature time curve in ${ }^{\circ} \mathrm{C} \times$ Sec. 
Calculation of the caloric input of the indicator creates some problems. Before each injection the portion of the catheter inside the dog contains injectate which has equilibrated to the dog's temperature. In our catheters this volume is approximately $0.4 \mathrm{cc}$. This volume has to be subtracted from the volume delivered by the syringe to obtain the net volume input. Immediately following injection this portion of the catheter contains injectate at some temperature below that of the dog's blood. This will slowly equilibrate across the catheter wall to the dog's temperature constituting an additional indicator input. This results in a prolonged tail to the thermodilution curve, but due to the relatively long time constant of the residual input compared to the bolus input, we found this effect to be negligible.

For each dye curve $1.2 \mathrm{ml}$ of $2.5 \mathrm{mg} / \mathrm{ml}$. Indocyanine green dye was injected into the pulmonary artery from a calibrated Robertson pipette, using a $10 \mathrm{ml}$ flushing syringe. The Harvard withdrawal pump was used to withdraw blood at a constant rate of $43 \mathrm{ml} / \mathrm{min}$ from the sensing catheter. The blood passed through a dye densitometer to obtain a dye dilution curve. A one way valve system allowed the blood to be returned to the dog through the femoral vein after each measurement. Two three way stopcocks in the sampling line allowed the blood to either pass directly through the densitometer for the recording of dye-dilution curves or through a calibration loop. The loop acted as a mixing chamber and consisted of a short piece of rubber tube $5 \mathrm{~cm}$ long connected to a tygon tube approximately $16 \mathrm{~cm}$ long and $6.0 \mathrm{~mm}$ internal diameter, filled with siliconized glass beads (Figure 1). Before each study the loop was flushed and filled with heparinized saline. For each calibration, blood was drawn through the loop at a constant rate. A known quantity of dye was injected through the rubber tubing using a microliter syringe. Thus a non-recirculating dye curve was inscribed. A dye calibration factor was calculated from a knowledge of flow, curve area and quantity of dye injected. This dynamic method of calibration was first described by Sparling ${ }^{6}$ and has been further evaluated by other investigators..$^{7-10}$ It has the advantages that it eliminates in vitro mixing of dye with blood, and minimizes errors caused by instability of the dye solution. ${ }^{9}$

Frequent determinations of dye calibration were made and were found to be linear. Measurements of cardiac output by thermodilution and dye were alternated. After each thermodilution the injectate catheter was flushed with heparinized saline as 3 per cent saline will cause precipitation of indocyanine green dye.

Dye and thermal dilution curve areas were evaluated by planimetry. If drifting of the base line occurred, the slope before the onset of the curve was determined and extrapolated. Dilution curve downslopes were extrapolated by a tangent method described by Graesh and Ward. ${ }^{11}$

\section{Results}

The results of 74 comparisons of cardiac output measured by the thermal dilution and the dye dilution methods are plotted in Figure 2. The results range from 1.76 to $6.18 \mathrm{l} / \mathrm{min}$. The correlation coefficient between the two methods is 0.89 . The mean difference in cardiac output (dye-thermal dilution), is $0.35 \pm 0.051 / \mathrm{min}$. In two dogs 19 comparisons were made after dextran infusion to create pulmonary 


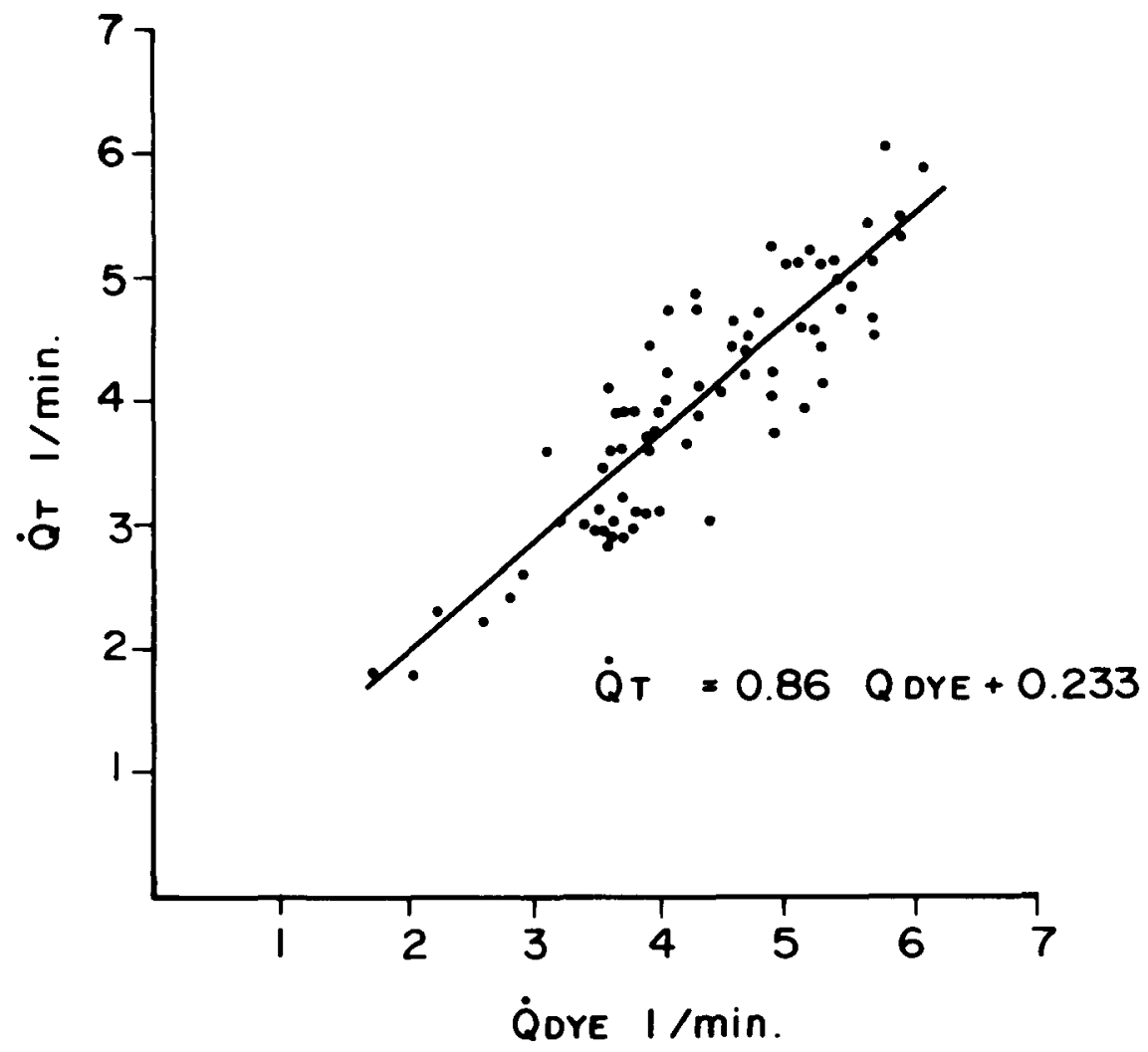

FIGURE 2. Comparison of cardiac output measured by dye ( $\dot{\mathbf{Q}}$ Dye) and thermodilution (Q்T) methods in control dogs.

oedema. The results, ranging from 1.41 to $7.7 \mathrm{l} / \mathrm{min}$ are plotted in Figure 3. The coefficient of correlation between the two methods is 0.88 . The mean difference in cardiac output (dye-thermodilution) is $0.23 \pm 0.21 \mathrm{l} / \mathrm{min}$. A plot of all the results combined is shown in Figure 4. The correlation coefficient of the combined data is 0.88 . The mean difference in cardiac output is $0.33 \pm 0.06 \mathrm{l} / \mathrm{min}$. Table I summarizes the results.

\section{Discussion}

Thermodilution is analogous to any other indicator dilution technique used for the measurement of cardiac output; consequently a knowledge of the amount of indicator injected is required. Accurate measurement of the caloric input of the indicator presents problems. Handling of the syringe will change its caloric content. During injection the temperature of the injectate constantly changes because of heat exchange with the wall of the catheter and surrounding tissues. Mathematical correction for this loss of indicator during injection has been made under conditions simulating the experiment ${ }^{12,13}$ or by calorimetric determination of heat transfer in a given injection system. ${ }^{14}$ However, the amount of indicator added depends upon the difference between the temperatures of the blood and injectate before mixing 


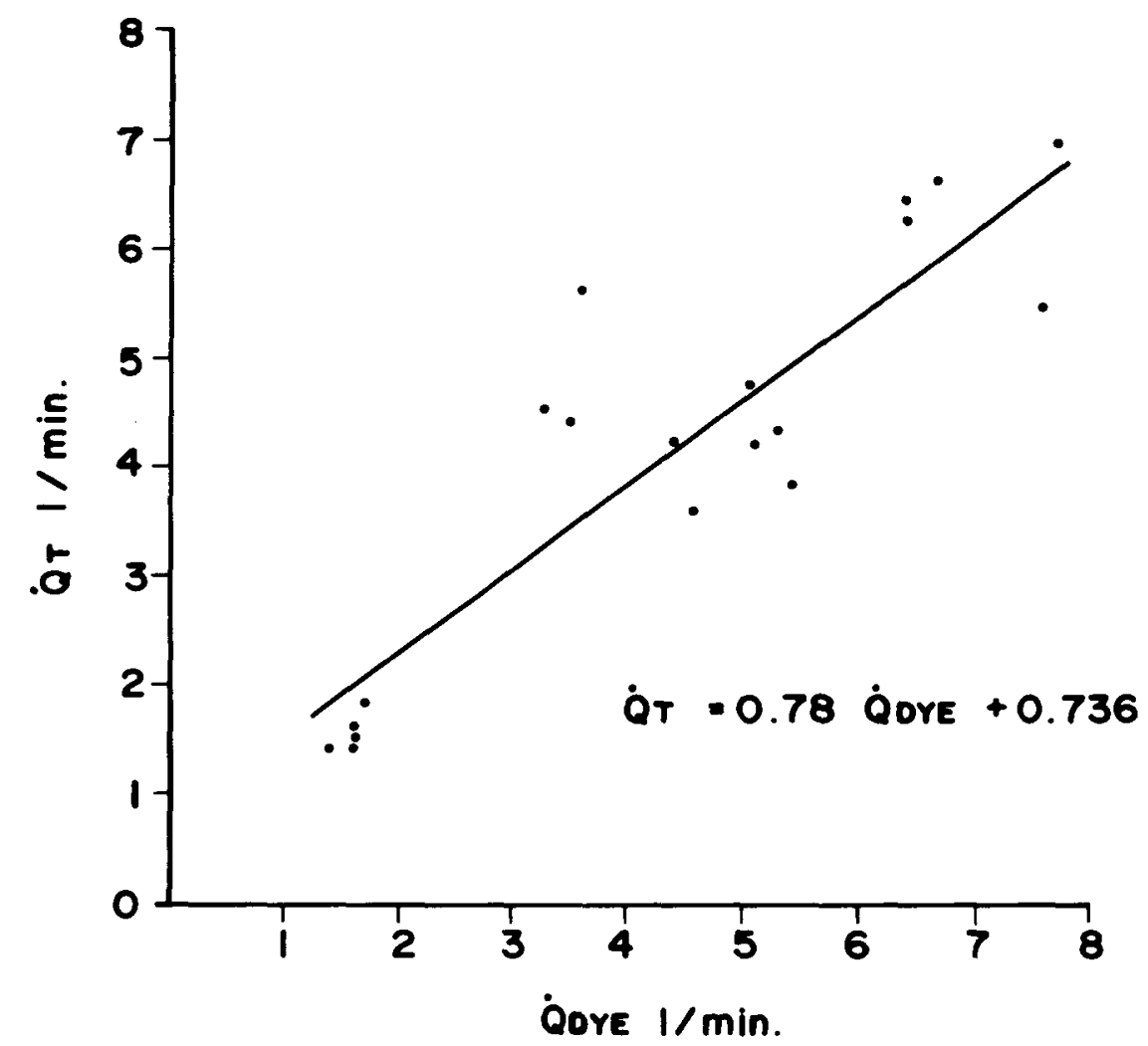

Figure 3. Comparison of cardiac output measured by dye and thermodilution methods in dogs with induced pulmonary oedema.

TABLE I

\begin{tabular}{lccc}
\hline \multicolumn{1}{c}{ Dogs } & $\mathrm{n}$ & $\begin{array}{c}\text { Mean Differences } \\
\hat{Q}_{\mathrm{DYE}}-\mathrm{Q}_{\mathrm{T}}\end{array}$ & $\begin{array}{c}\text { Correlation } \\
\text { Coefficient }\end{array}$ \\
\hline Normal & $\mathbf{7 4}$ & $0.35 \pm 0.05$ & 0.89 \\
Edema & $\mathbf{1 9}$ & $\mathbf{0 . 2 3} \pm 0.21$ & $\mathbf{0 . 8 8}$ \\
Combined & $\mathbf{9 3}$ & $\mathbf{0 . 3 3} \pm 0.06$ & $\mathbf{0 . 8 8}$ \\
\hline
\end{tabular}

takes place. ${ }^{5}$ Therefore, monitoring the temperature of the injectate at the catheter tip will give the most accurate determination of the heat content of the injectate.

Another criterion of indicator dilution techniques is no loss of indicator between the site of injection and detection. Heat differs from the majority of indicators because it will cross the vessel wall. Fortunately this temperature exchange is reversible. The time taken for this exchange will depend upon a number of factors; the location of the injection and detection sites, the cardiac output and the physical properties of the surrounding tissues and fluid. However, provided all the indicator returns to the vessel the determination of cardiac output will be accurate and only the shape of the dilution curve will be distorted. 


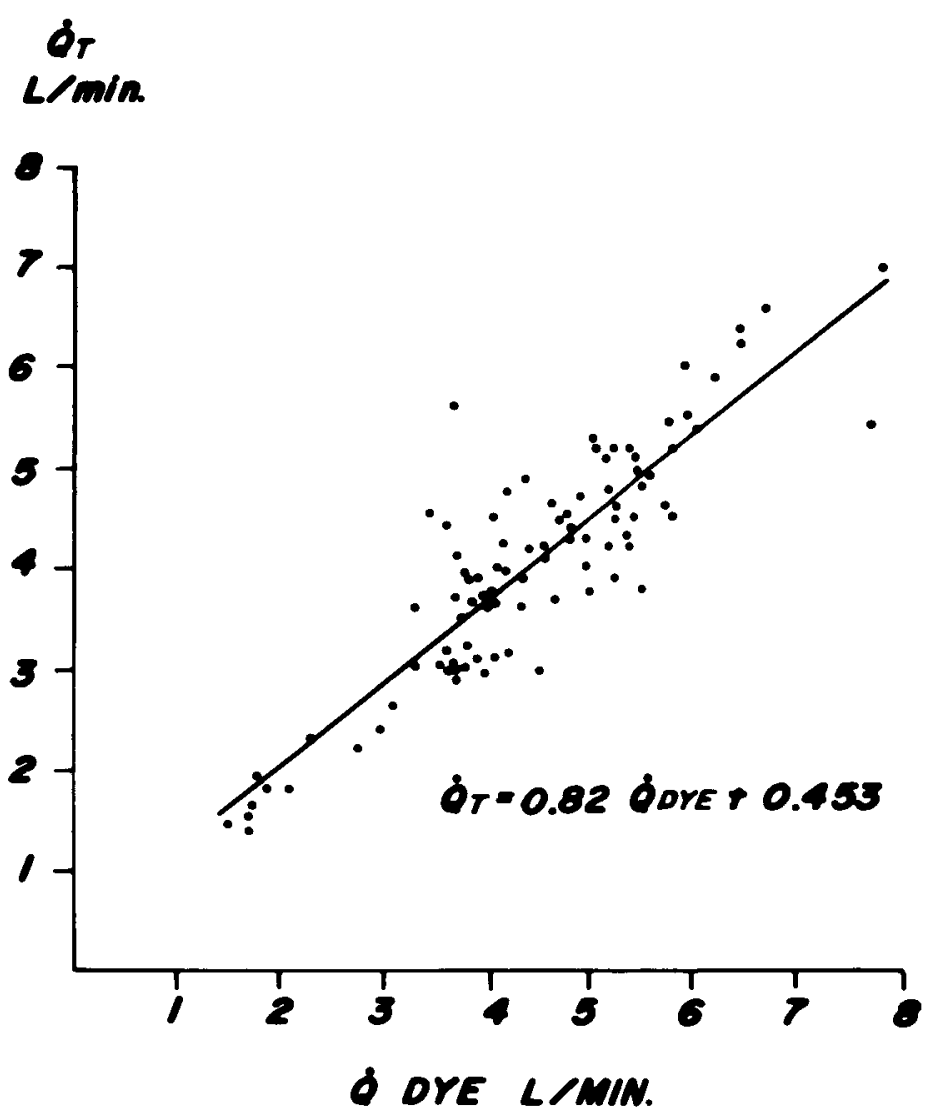

Figure 4. Comparison of cardiac output measured by dye and thermodilution methods for all dogs.

Theoretically there could be an irreversible exchange between blood and gas in the lung, mediastinal contents, and chest wall. The good agreement between dye and thermal dilution combined data is evidence that there was not a significant non-returnable loss of heat. If there was, the area under the thermodilution curve would be reduced, resulting in too large an estimation of cardiac output. This did not occur (Table I).

Hosie $^{5}$ suggested that considerable loss of indicator seemed inevitable in pulmonary oedema, resulting in over-estimates of cardiac output. Ganz ${ }^{13}$ also stated that the aorta could not be used as the sampling site when the pulmonary capillaries are surrounded with significant amounts of fluid. Our data do not support the hypothesis that there is a significant non-returnable loss of heat in pulmonary oedema. Two of the dogs that had received dextran to produce pulmonary oedema showed good agreement between dye dilution and thermal dilution (Table I). This indicates that there was no significant irreversible loss of heat in the pulmonary vascular bed even in pulmonary oedema. However, the shape of the dilution curves was distorted (Figure 5). There was a slightly prolonged build-up 


\section{THERMODILUTION CURVES}

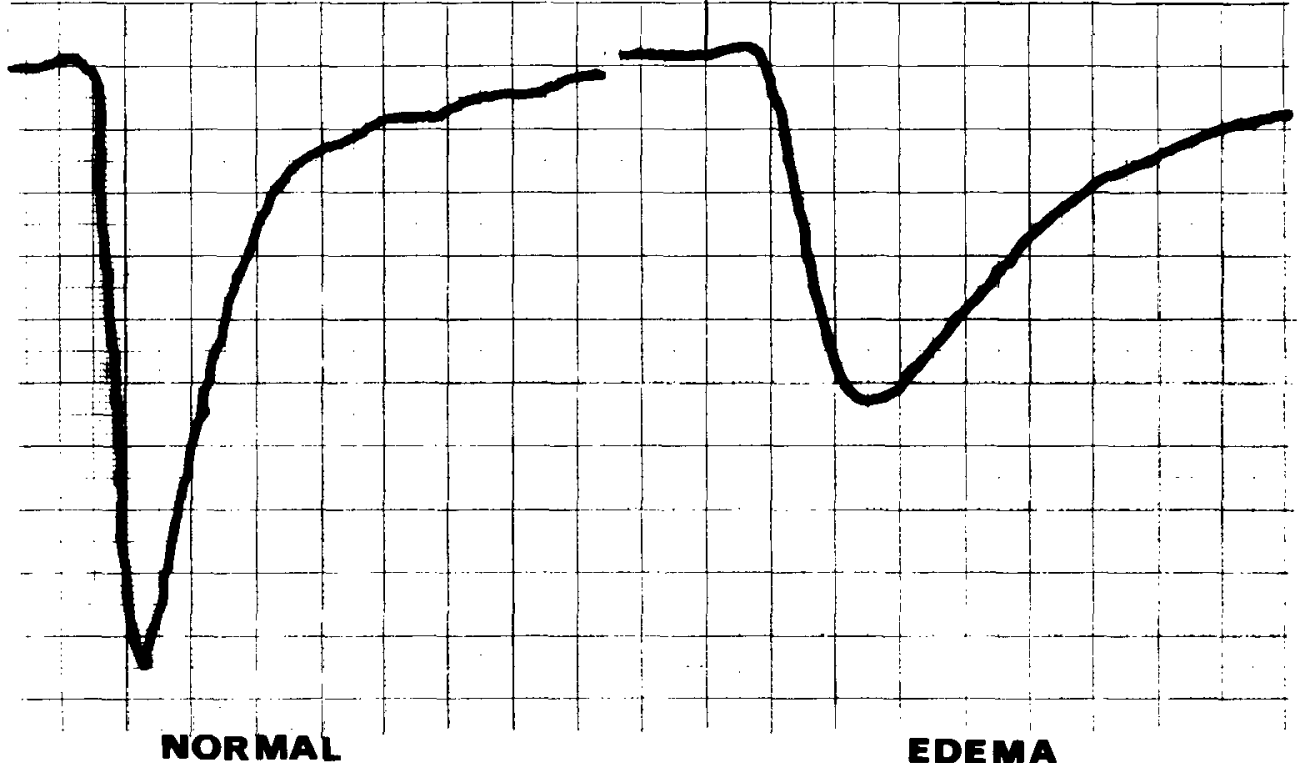

Figure 5. Examples of thermal dilution curves in a dog before and after the induction of pulmonary oedema.

time and a decreased peak height, but the major change was in the down slope, which was excessively prolonged. This distortion of the thermodilution curve in pulmonary oedema can be used to advantage, as prolongation of the mean transit time can be used to quantitate pulmonary oedema. In these experiments we were quantitating pulmonary oedema, which requires an intravascular indicator and is the reason for the use of 3 per cent saline as injectate. ${ }^{15}$

The thermodilution technique offers a number of advantages. It has virtually unlimited repeatability, as any physiological solution can be used as an indicator. Ease of calibration, minimal recirculation, relatively uncomplicated instrumentation and the potential for quantitating pulmonary oedema are assets, and the withdrawal of blood is not essential.

\section{SUMMARY}

A method for measuring cardiac output by thermodilution is described. This method is compared with the dye dilution technique in normal dogs and in dogs with pulmonary oedema. There was good agreement between the two methods. In view of the advantages of the thermodilution technique it should be suitable for monitoring cardiac output in the clinical setting.

\section{RÉSUMÉ}

La thermodilution est similaire à toute autre technique de dilution avec indicateur utilisé afin de mesurer le débit cardiaque; conséquemment, une connaissance de la quantité de l'indicateur injecté est nécessaire. 
La détermination exacte de l'apport calorique de l'indicateur présente certains problèmes - la manipulation de la seringue modifie le contenu calorique. Durant l'injection, la température de la substance injectée est constamment modifiée à cause des échanges thermiques effectués contre la paroi des catheters ou des tissus environnants.

Des corrections mathématiques se rapportant à cette perte constatées durant linjection furent établies dans des conditions simulant l'expérience 12, 13 ou par calcul calorimétrique du transfert thermique dans un système d'injection donné. Cependant, la quantité d'indicateur ajouté dépend de la différence entre la température du sang et celle de la substance injectée avant que cette demière y soit mélangée.

Ainsi, le calcul de la température de la substance injectée au bout du cathéter, donnera la réponse la plus exacte du contenu thermique de celle-ci.

Un autre critère important dans les techniques de dilution suppose qu'il n'y a pas de perte de l'indication entre son site d'injection et de récupération.

La chaleur diffère de la majorité des indicateurs du fait qu'elle traverse la paroi vasculaire. Heureusement, cet échange thermique est réversible.

La période de temps allouée pour cet échange dépend de plusieurs facteurs : la localisation de l'endroit d'injection et de récupération, le débit cardiaque et les propriétés physiques des tissus et liquides avoisinnants. Cependant, pour autant que tout l'indicateur retourne aux vaisseaux, le calcul du débit cardiaque sera exact, seulement la courbe de dilution sera modifiée.

En théorie, il pourrait se produire un échange irréversible entre le sang et les gaz du poumon, le milieu médiastinal et la paroi thoracique. Cependant, l'étude comparée entre la méthode thermique et calorimétrique démontre qu'il n'y a pas de perte significative de chaleur. Si un tel fait s'était produit, la zone sous la courbe de thermodilution aurait été réduite, entraînant un estimé exagéré du débit cardiaque. Ceci ne s'est pas produit (Table I). Hosie ${ }^{5}$ signale qu'une perte considérable de l'indicateur semblait inévitable dans l'oedème pulmonaire, entraînant un débit cardiaque sur-estimé. Ganz ${ }^{\mathbf{1 3}}$ mentionne aussi que l'aorte ne peut pas être utilisée comme point d'échantillonnage lorsque les capillaires pulmonaires sont inondés d'une quantité significative de fluide.

Nos données ne concordent pas avec l'hypothèse voulant qu'il y ait une perte significative de chaleur non transmissible dans l'oedème pulmonaire.

Deux des chiens qui ont reçu du dextran afin de produire un oedème pulmonaire montrèrent une bonne compatibilité entre la méthode de dilution calorimétrique et thermique ('Table I).

Ceci indique qu'il n'y eut pas de perte significative et irréversible de chaleur dans le lit vasculaire pulmonaire même durant un oedème pulmonaire. Cependant, la courbe de dilution fut modifiée (fig. 5). La partie ascendante de la courbe fut très légèrement allongée et le sommet fut diminué, mais le changement majeur fut enregistré sur la partie descendante, elle fut excessivement prolongée. Cette distorsion de la courbe de thermo dilution lors d'un oedème pulmonaire peut être utilisée avantageusement du fait que la prolongation de la période de transit pourrait permettre de mesurer quantativement l'oedème pulmonaire. Ces expériences nécessiteraient quantitativement la présence d'un indicateur intra-vasculaire et c'est pourquoi un salin à 3 pour cent était employé. 
La méthode de dilution thermique offre de nombreux avantages; Elle a un pouvoir virtuel illimité permettant la répétition de l'expérience, étant donné que toute solution physiologique peut être employée comme indicateur.

La calibration facile, la circulation minimale, l'instrumentation relativement simple et le potentiel permettant d'établir quantitativement la magnétude de l'oedème pulmonaire sont autant d'avantages favorisant cette méthode.

Enfin, disons qu'il n'est plus nécessaire de retirer du sang pour obtenir des résultats.

\section{ACKNOWLEDGMENTS}

We gratefully acknowledge the expert technical assistance of Mr. B. Dober, and Mrs. Yvonne Gaiger.

Nembutal was supplied by Abbott, Dextran by Pharmacia (Canada) and Indocyanine Green Dye by Hynson, Westcott and Dunning Inc.

This work was supported by Medical Research Council of Canada grant number 3-501-269-20, the Ontario Tuberculosis and Respiratory Disease Association grant number 3-333-269-11, and the St. Michael's Research Society.

\section{REFERENCES}

1. Prime, F.J. \& Grax, T.C. Difficulties in the application of Fick principle to determine cardiac output in anaesthesia. Curr. Res. Anesth. 31: 347 (1952).

2. Richardson, D.W., Wyso, E.M., Нecht, A.M., \& Fitzpatrick, D.P. Value of continuous photoelectric recording of dye curves in the estimation of cardiac output. Circulation 20: 1111 (1959).

3. Sinclatr, J.D., Sutterer, W.F., Fox, I.J., \& Wood, E.H. Apparent dye-dilution curves produced by injection of transparent solutions. J. Appl. Physiol. 16: 669 (1961).

4. Fecier, G. Measurement of cardiac output in anaesthetized animals by a thermo-dilution method. Quart. J. Exp. Physiol. 39: 153 ( 1954 )

5. Hosie, K.F. Thermal-dilution technics. Circ. Res. 10: 491-504 (1962).

6. Sparling, C.M., Mook, G.A., Nieveen, J., Van der Slikke, L.B., \& Zijlstra, W.G. Calibration of dye dilution curves for calculation of cardiac output and central blood volume. Congres Européen de Cardiologie. Acta Tertee Europaei De Cardis Scientia Conventus. Pars-Alterap. 595 Rome Excerpta Medica (1960).

7. Emanuel, R. \& Norman, J. Evaluation of a dynamic method for calibration of dye dilution curves. Brit. Heart J. 25: 308 (1963).

8. Emanuel, R., Hamer, J., Chianc, B-N., Norman, J., \& Manders, J. A dynamic method for the calibration of dye dilution curves in a physiological system. Brit. Heart J. 28: 143 (1966).

9. VöLlm, K.R. \& Rolett, E.L. Calibration of dye dilution curves by a dynamic method. J. Appl. Physiol. 26: 147 (1968).

10. Shinebourne, E., Fleming, J., \& Hamer, J. Calibration of indicator dilution curves in man by the dynamic method. Brit. Heart J. 29: 920 (1967).

11. Graesch, P.A. \& WARD, R.J. Two graphical methods for determination of dilution curve area. J. Lab. and Clin. Med. 66: 830 (1965).

12. Ganz, W., Donoso, R., Marcus, H.S., Forrester, J.S., \& Swan, H.J.C. A new technique for measurement of cardiac output by thermodilution in man. Amer. J. Cardiol. 27 : 392 (1971).

13. Ganz, W. \& Swan, H.J.C. Measurement of blood flow by thermodilution. Amer. J. Cardiol, 29: 241 (1972).

14. Goodyen, A.V.N., Huvos, A., Eckrardt, W.F., \& Ostberg, R.H. Thermal dilution curves in the intact animal. Circulation Res. 7: 432 (1959).

15. Noble, W.H. \& Severinghaus, J.W. Thermal and conductivity dilution curves for rapid quantitation of pulmonary oedema. J. Appl. Physiol. 32: 770 (1972). 